understand the hazard"'. The document also criticizes as unwarranted Professor McCarthy's inferences about the production of aerosol particles carrying virus from safety cabinets used in the smallpox laboratory.

Those questioned earlier this week about the ASTMS allegations were unwilling to comment without an opportunity to study the text. Those witnesses at the court hearing who were reached by telephone said, however, that they stood by their evidence.

The coroner at the inquest on Mrs Parker's death had let it be known in advance that he did not wish to go over ground already covered at the court hearing. $\mathrm{Mr}$ Clive Jenkins, General Secretary of ASTMS, has nevertheless written to him with a copy of the document. He has also written to $\mathrm{Dr}$ Gerald Vaughan, Minister of Health, demanding that the Dangerous Pathogens Advisory Group be reconstituted by including public interest and trades union representatives, and that the government should make clear that it is prepared to spend the monies necessary to make laboratories in universities and hospital pathology departments safe.

\section{Law of the Sea}

\section{Hurdles to jump}

\section{Washington}

Final agreement on international legislation covering deep-sea mining could prove more elusive than suggested by the successful completion of negotiations on a draft United Nations Law of the Sea Treaty in Geneva last month. Even if - as indeed seems likely - a draft treaty is finally agreed and signed by member nations after a final meeting in Caracas early next year, there remains the question of ratification, required of at least sixty states. And this could prove a major stumbling block, particularly in the US Senate.

Member companies and trade associations of the American Mining Congress (AMC) are meeting in San Francisco next weekend to decide their position on the draft treaty which emerged from the Geneva negotiations, the culmination of more than twenty years of talks.

Prior to the Geneva meeting, the congress had expressed strong reservations about some aspects of the US negotiating position, claiming that the chief US negotiator, Ambassador Elliott Richardson, was giving away too much in his eagerness to get the treaty signed.

Many of the companies still express the same reservations. And the AMC's views could be crucial in determining whether the US Congress decides to back the treaty. Earlier this year, following strong pressure from the mining companies, Congress passed a unilateral law defining conditions under which US companies could engage experimentally in deep-sea mining from
1981 unless the UN treaty is in force. Similar actions by Germany, and proposed actions by the United Kingdom and France, are among the factors said to have precipitated the Geneva agreement.

The stakes are high. Total investments of more than $\$ 1,000$ million are expected to be made by each of the four major consortia now preparing to engage in deep-sea mining, primarily for manganese nodules containing nickel, cobalt and copper. The companies are demanding, above all, a degree of certainty about a reasonable return on their investment.

Among the areas that the mining companies are unhappy about are:

- The lack of guaranteed representation of the United States on the 37-member council of the International Seabed Authority, even though the Soviet Union is given three seats, a position which one executive predicted that the Senate would find difficult to accept.

- The participation as signatories of the treaty of organizations other than UN member states, such as the Palestine Liberation Organization. This could entitle such organizations to share in the profits of deep-sea mining which the US companies are required to provide to the authority for distribution as development aid.

- The requirement that mining companies should make their mining technology available to other countries who demand it.

The major question now facing both US and UN negotiators is whether any movement is possible on these issues before the treaty is signed next year and, if not, whether they are likely to provide a sufficient obstacle to prevent Senate ratification, given the many other advantages to the United States in an international treaty that covers all aspects of nations' rights to the oceans.

None of these reservations is, in itself, expected to be a major stumbling block to the final treaty. Nor, among those who are strong supporters of the treaty, is there any desire to open up discussion again in case the whole package begins to unravel. But claims that "it is all over bar the shouting" may turn out to be a little premature.

David Dickson

\section{Overseas students}

\section{Some win, some lose}

British universities and colleges appeas to differ markedly in their expectations of numbers of overseas students in the coming academic year. Some universities - a litte to their surprise - expect there will be very little change between last year and this in the numbers of students from overseas. Others expect that numbers will be, by contrast, substantially reduced.

The issue has become a lively topic of conversation among academic registrars because the coming academic year is the first in which the steep increases of student fees decreed by the British government a year ago will begin to bite. The fees apply only to new students, or to students embarking on new courses. Registrars are also quick to point out that at this stage in the academic year, before students have actually registered and paid their fees, estimates of how many will turn up are bound to be provisional.

The universities where there appears to have been very little change in the demand for places include the University of Salford and Loughborough University of Technology. At both institutions (as at most universities) overseas students are now required to produce not merely their fees but a financial guarantee from a bank or some scholarship awarding body, which may require that a student should have $£ 6,500$ at his disposal in each of three consecutive academic years.

Elsewhere, the preliminary figures suggest that some kinds of courses are likely to suffer more than others. Applications for places on MSc courses appear to be comparable with last year's at some institutions, which are nevertheless guessing that overseas students will be reduced by ten per cent or more in undergraduate and $\mathrm{PhD}$ courses.

One of the difficulties of estimation is that students who have nominally accepted places fail to turn up by the beginning of term, for most British universities early in October. In normal years, it is expected that overseas students will apply to several universities but in the end accept a place at only one of them, which means that a certain amount of double counting is unavoidable at this stage in the academic year. But some also fail to turn up for reasons which are never explained. Some registrars fear that difficulties over finance may increase the numbers in this category in the coming year.

With all these reservations, Imperial College, London says that there has been a "discernible" reduction of the numbers of completed applications from overseas. Portsmouth Polytechnic, one of the largest institutions of higher education in the United Kingdom, is similarly affected and wonders ruefully whether the explanation may not be the rules which require polytechnics to charge fees laid down by the Department of Education and Science. This year, polytechnic fees for overseas students are nominally some $£ 300$ to $£ 400$ greater than those in universities.

While registrars at all kinds of institutions agree that the present period is more confusing than any other within living memory, most of them appear to be mildly encouraged that the decline in numbers has not been as dramatic as some of them were fearing earlier this year. Unless there is a sharp deterioration in the next few weeks, overseas student numbers are unlikely to be reduced by anything like the 50 per cent feared by some or by the 30 per cent which appears to have been the base-line for financial planning for the coming year. 